\title{
UK universities get another funding boost
}

[LONDON] British universities were told last

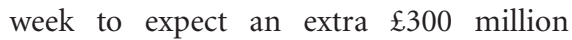
(US\$500 million) over the next three years to support research through the block grants they receive from the Department for Education and Employment.

The money comes on top of the two $\mathfrak{3} 300$ million sums that the government and the Wellcome Trust had earlier announced they are to provide for a new fund to rebuild and refurbish university laboratories over the same period (see Nature 394, 209; 1998).

It is also in addition to the extra $£ 400$ million for research council projects, much of which is likely to be spent in universities. Although the precise distribution of the funding over the three years has not yet been decided, it represents a significant increase in the amount that universities currently receive directly from the government to support research in their science departments.

There was a broad welcome from the university community last week for the extra money, which, together with the earlier announcement, goes a long way towards meeting suggestions made last year by the Dearing commission on higher education (see Nature 388, 413; 1997).

Diana Warwick, chief executive of the Committee of Vice-Chancellors and Principals, for example, described both the new funds for research and a separate commitment by the government to provide an extra 35,000 university places next year as "excellent news".

There was also considerable relief that, at least in principle, the government has decided to retain the 'dual support' system. This is the system under which universities are supposedly left free to decide how to allocate their core government funding to basic scientific infrastructure, with extra money for individual projects being provided through the six research councils on a competitive basis.

"We are delighted that the government is continuing to back the dual support system," says Brian Fender, chair of the Higher Education Funding Council for England, one of the four regional bodies through which government support for universities is distributed, which will jointly receive an extra $\mathfrak{E} 50$ million for research next year.

But the government has also sent out a clear signal that it intends to reduce the degree of autonomy that universities enjoy in deciding how to spend their research funds. This follows growing concern in government circles that universities do not always spend such funds as it would like (for example, by using them to fund a large number of researchers on short-term contracts, rather than investing in equipment).

Significantly, the Office of Science and Technology (OST), through John Cadogan,

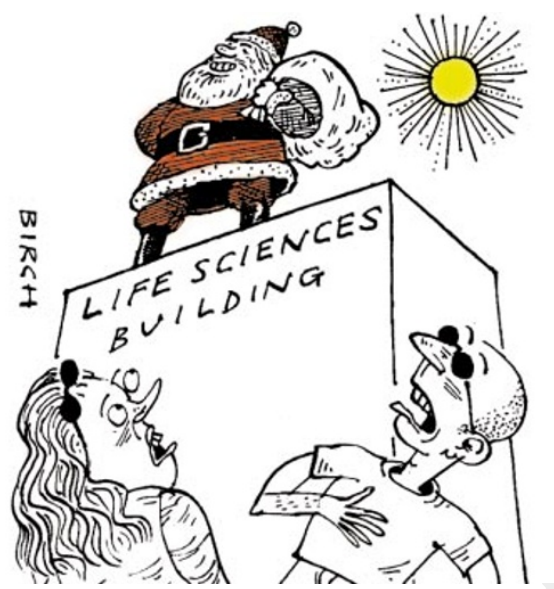

the director general of research councils, will co-chair with Mike Dexter, the director of the Wellcome Trust, the new fund being jointly set up with the trust to cover university equipment and infrastructure.

The Dearing committee had proposed an alternative route in which all research councils would be required to increase the amount of overhead paid automatically on grants to university researchers from its current level of 46 per cent to 60 per cent to cover these types of costs.

But critics of this suggestion argue that, despite the government's continued emphasis on the need for greater 'transparency' in internal accounting procedures, in many British universities these remain insufficiently developed to ensure that the money goes to genuine overhead costs.

The new fund has helped to persuade the Wellcome Trust to shoulder part of the costs of renewing the research infrastructure of British universities — something it had previously been reluctant to do - and has allowed the OST to help target money and keep a close eye on how it is spent on a project-by-project basis.

But it has also raised concerns about how universities are likely to find the money to renew facilities not directly linked to research priorities. "Where will they find the

money for the non-science sections of their libraries, or for sports facilities used by scientists?" asks one observer.

Others point out that last week's statements by the Department for Education lacked any commitment to renew equipment used for teaching, rather than research. Furthermore, the government has done little to reduce the financial disincentives to a research career by, for example, failing to allocate extra money to increase $\mathrm{PhD}$ stipends as the research councils had requested (although leaving the councils free to do this if they so choose out of their allocated research budgets).

Behind all this is a concern that the strong emphasis placed by government statements last week on the importance of the life sciences in general - and genomics-related research in particular - could translate in a funding swing away from the physical sciences, with potentially severe long-term consequences for the economy.

Lynne Jones, for example, a Labour member of the House of Commons select committee on science and technology, who trained as a biochemist, reflected such concerns during a parliamentary debate last week when she asked the government for assurances "that physical science will not miss out in the bonanza".

Government officials argue that they are well aware of the potential dangers involved, particularly as the Wellcome Trust is, by virtue of its trust deeds, restricted to funding projects in the biomedical sciences. One response of such officials has been to underline the important contribution made by other disciplines, such as computing and instrumentation engineering, to the success of genome sequencing research.

But many say they will be watching closely and warily how the new money is divided between scientific disciplines, and how what they describe as the excitement of other, physics-based disciplines is reflected in the final resource allocation.

David Dickson

\section{New Zealand enjoys science jamboree}

[DUNEDIN] The city of Dunedin in New Zealand's South Island has marked the 150th anniversary of its foundation by Scottish immigrants by mounting the country's largest ever promotion of science. With an attendance of around 25,000, the two-week festival was organized by the local community and museum with the University of Otago, which was established by Scottish settlers in 1869 as the country's first university.

A spectacular finale in the city centre saw 100 people walking unharmed on red hot charcoal after physicist John Campbell of Canterbury University had given them an explanation of the physics of thermal conductivity.

Expatriate New Zealander Sir Ian Axford, director of the Max Planck Institute for Aeronomy in Germany, commented during the festival on the low proportion of national expenditure New Zealand devotes to research by international standards. $\mathrm{He}$ said New Zealanders must increase spending "pretty quick" if they want to become internationally competitive. 